\title{
Learning Polyhedrons Based On It
}

\author{
Siti Hajar \\ Madrasah Tsanawiyah Negeri 1 Kota Malang \\ Email: sitihajar6556@gmail.com
}

\begin{abstract}
Learning resources and media play very important roles in learning activities in the classroom. Various learning resources complemented with interactional media will encourage the learners to be more active in the classroom. The objective of this present research is to analyze what learning resources and media are used by the teacher in learning polyhedrons. This research was conducted in MTs N Malang 1. The methods of data collection were observations and interviews. To obtain the data, the researcher made observations during learning activities and then compared the data from the observations and those of the interviews with the teacher concerned and with one of the students joining in the learning activities. The data were qualitative in nature. Based on the data analysis, it was revealed that learning resources and media used were IT-based. The learning resources were electronic books and the package books for Grade VIII and the media were the property from Power Point. The learningbased IT for students Grade VIII-A MTs N Malang 1 gave good effects on all students, so that all of them joined in the learning activities actively.
\end{abstract}

Key words: learning resources and media, polyhedrons

\section{INTRODUCTION}

Education is closely related to life, since it not only deals with the transmission of cultures from one generation to the next but also the spread of knowledge through learning activities given by others or done in an autodidact way (Dewey, 1916). The Law No. 20 Year of 2003 on National Education System defines that education is a conscious and planned effort to realize the learning condition and process in such a way that the students can actively develop their potential in order to possess religious spiritual power, selfcontrol, personality, intelligence, noble character, and competences needed by him/herself, the society, the nation and the country. From the description, it can be concluded that it is necessary to have a learning atmosphere and learning processes that may support the students to make them develop their potentials actively. One of the ways in realizing such active students is by creating a classroom condition that enables them to learn (Hudoyo, 2005). Teachers become the ones who are mostly responsible for the learning management in the classroom. Learning resources and media used by the teachers in the learning process really determine the situation in the classroom.

Learning resources are a power covering messages, people, materials, tools, techniques and environment made use of in the learning process either individually or in groups, directly or indirectly, partly or as a whole (Hamalik, 1989; Subandijah, 1983; AECT,1996). In learning activities, learning resources in general are in the form of texts, 
video, software and other materials that may help students learn (Anonymous, 2008). Learning resources in general are closely related to learning media. Learning media are defined as the tools used as the media to present messages and may stimulate students' thoughts, feelings and advancement in such a way that may promote the teaching-learning process to occur (Sabri, 2005). However, in a more specific term, the term media in the learning process tends to be perceived as tools or graphics, photographs, or electronics to catch, process, or to rearrange visual or verbal information (Kosasih, 2007).

Geometry occupies a special position in the mathematics curriculum due to many concepts contained in it. From mathematical point of view, geometry provides approaches to problem solving, for instance, pictures, diagrams, coordinate systems, vectors, and transformations. Geometry is also a medium for learning mathematical structures (Burger \& Culpepper, 1993). One of sub sections in geometry in Grade VIII is polyhedrons.

The learning of polyhedrons in Grade VIII covers the concepts of an introduction, an understanding, the nature, the characteristics and the determination of the area and volume of polyhedrons consisting of cubes, rods, prisms and pyramids. The learning of polyhedrons is considered to be difficult by students (Aisah, 2012), therefore, the visualization in the form of geometric illustrations is beneficial for understanding the concepts. This visualization may be used as the media for developing the students' understanding, attention, and interest to the problem, definition, guess, formation of preliminary understanding and their attention to the relation and the use of visual facts as the basis for understanding and reasoning factually or intuitively (Ponter, 2009).

\section{RESEARCH METHOD}

Research method is a series of ways used in a scientific process. Research method is used to guarantee that the principles of a research are implemented so that the end result of the research are scientifically accountable. The focus of this present research was on understanding how the learning resources are used to learning polyhedrons in Grade VIII. To obtain the data, a qualitative approach was employed where the subject of this present research was the teacher in the Mathematics field study in Grade VIII. Qualitative research is an approach which is also called as an investigation approach since the researcher collected data by facing and interacting with the people directly in the research site. Qualitative research may also mean as a research type of which the findings are obtained through statistical procedures or other forms of calculation. However, the data collected from such a qualitative research may be analyzed using a calculation.

Research procedure is part of a research. The stages of this present research consisted of two namely observations and interviews stages. The observation stage was conducted during the learning activities, while the interview stage was made when the learning activities had been done. The researcher made interviews with the teacher of Mathematics Grade VIII-A and a student in Grade-A since this research intended to refer to learning resources and media used by the teacher to present the material of polyhedrons to students in Grade VIII-A. Moreover, it was intended that the data obtained from the observations could be compared with those of the results of the interviews without reducing the validity of the data from the results of observations.

Data analysis is a process of arranging data so that they can be interpreted. Data interpretation in this present research means giving the meaning to the analysis, explaining 
the pattern or category, looking for the relations among various concepts reflecting the research' perspective. The results of the interpretation are also not generalization in a qualitative meaning, but working hypotheses that should be done through observations in the classroom. Data analysis in this present research consisted of 1) the analysis of observations in the classroom, and 2) the analysis of interviews with the teacher.

\section{RESULT}

Based on the research made in MTsN Malang I, it was known that the learning resources used in learning polyhedrons varied. In the learning activities, the learning resources used by the learners were Package Book Grade VIII semester 2, Electronic School Book, Students' Worksheets, and other Mathematics books, beside the resources given by the teacher. The learning resources in the form of the package books and students' worksheets in learning polyhedrons were possessed by the teachers and the students. The package Books for Grade VII were possessed and distributed by the school, the Students' Worksheets, which contains exercises, were bought by the students.

In learning mathematics, the learning resources were the combination from the Mathematics package books Grade VIII, Electronic School Books, and Students' Worksheets and also the knowledge of the teacher. The teacher usually used other Mathematics package books to give the students exercises for homework, improvement and enrichment. Therefore, it can be concluded that the main learning resources used by the students Grade VII-A MTsN 1 Malang in learning polyhedrons were Electronic School Books, Package Books and Students' Worksheets. The forms of the learning resources are softcopy and hardcopy. The learning resources in the form of hardcopy are Mathematics package books Grade VIII and Students' Worksheets, while for Electronic School Book is in the form of either softcopy or hardcopy. In general, the teacher used the Electronic School Book when he presented the materials using LCD projector. At that time, the teacher combined the examples of exercises in the Electronic School Book and the Students' Worksheets. The Electronic School Book was used in learning the polyhedrons when the teacher showed the summary of the materials via LCD projector in front of the classroom.

Based on the statement made by the Mathematics Teacher Grade VII-A, there were many benefits from the use of Electronic School Book, one of the benefits was the its form is flexible. It is in line with the results of an interview with the teacher Grade VIII-A: "Many benefits from using the Electronic School Book mam, besides as the complement of the Package Book and the Students' Worksheet, its softcopy may also be used by students from the low economic level to study at home or at school, without being printed to save money". From the statement it can be concluded that besides supporting knowledge, the Electronic School Book is chosen due to economic factors.

The package books used were Mathematics Books Grade VIII from some publishers. The books may help students understand the existing materials. There were other Mathematics package books which were generally used by students at home. The students always combined the knowledge from the learning activities at school and that from the complementary package books in the form of Mathematics Books from publisher $\mathrm{X}$. From the results of the interviews with the students, it was shown that in general the 
students used the book package from the publisher $\mathrm{X}$ without being ordered by the teachers. Some students also completed the exercises in the book.

In presenting the materials in the classroom, the teacher always made use of interactive media intended to make the learning process more maximal. Therefore, the learning of polyhedrons in Grade VIII-A would give positive impressions to the whole students. The interactive media used was Power Point via Laptop and LCD projector. Power point is one of the media used to present a property visually that may reach all students. Each slide in the power point was completed with an interesting animation to visualize the material of polyhedrons. The explanation and visualization of the material presented in the slides in front the class were clearer that the materials presented manually on the board. Learning activities based on IT using Power Point made the students more active and focus. It is in line with the statement made by one of the students Grade VIII-A, "If Power Point is used, learning mathematics is easier mam, the animations in the Power Point are good and vary so I easily understand the content". The Mathematics teacher also said the same: "I like to use Power Point as my media mam, it is easy to make and it facilitates me to implant concepts to the students, especially when I had to explain polyhedrons. I just added some animations in the pictures of cubes. This may substitute me to give explanations manually on the board."

The IT-based media the teacher made use of in teaching polyhedrons was the softcopy of the Electronic School Book, beside Power Point. The book was used as supplement materials that may be presented in LCd projector. This may save time in learning mathematics, and the time saved may be used by the teacher to enrich materials, exercises and also to give some advices. But, the teacher usually used the time to give exercises. Although in learning polyhedrons no time left, exercises were still given by the teacher amid the explanation of the materials on polyhedrons. Using the IT-based learning, the teacher should really prepare the materials before. The materials here were the teaching materials in Power Point or the software of other applications that may be used to present the materials or the materials that serve to help students understand concepts. The materials to present the should also be in the form or print out or hardcopy. When the teacher compared the materials from the Electronic School Book, the teacher did not give handouts or prints out from the Electronic School Book, since the students had possessed the soft files from the Electronic School Book.

Power Point is considered to give more benefits for the learning activities in mathematics, but from the results of the interviews it was shown that using Power Point or IT-based media such soft copy of the Electronic School Books via LCD projector also had some hindrances. The hindrance of using IT-based media could be grouped into two: internal and external. Internal hindrance is the hindrance coming from the components in the learning activities either from the teacher himself or the students. In learning polyhedrons, the hindrance in using the Power Point media was less preparation made by the teacher. The teacher did not give handouts to the students. In any learning activity using Power Point the teacher in general should always give a summary or print out from the slides presented in the class. But, the students were very enthusiastic and attractive in joining the learning polyhedron. The students were still focused and often asked the teachers when the explanation of a material was unclear. Beside internal hindrance, sometimes some external hindrances were faced in using the IT-based learning, for 
example, when the electricity was off. Learning materials using a recent technology must really depend on electricity. Although in learning polyhedrons the electricity was always on, the teacher had anticipated it. It is expressed by the Mathematics teacher Grade VIII-A as follows: , "If the electricity is off suddenly when I am explaining the material, I yeah ... explain it using the existing media mam, using the wardrobe for beam, room for cubes, and the like".

\section{DISCUSSION}

The result of the research made Indriyanti (2010) showed that most students liked learning activities which are innovative, not monotonous and those using Students' worksheet and property as the media. It is in line with the research result conducted in MTs N Malang 1. In the research, the researcher concluded that due to various and flexible learning resources and innovative media, the students were more active in joining in the learning process. To realize this innovative media, the teacher always tried to create the interesting learning condition so that students were more enthusiastic in the learning activity. It is proved from the use of animation in the media of power point in learning the polyhedron. Power point with a lot of animation would facilitate the students in accepting the teachers' explanation. Because of the media with a lot of animations, the students did not need to imagine of what was explained by the teacher. The students merely watched what was presented by their teacher. Moreover, the students could make used of the media many times, anywhere and anytime. This made the students moreeasy to study.

Another IT-based media in MTs N Malang 1 besides power point was Electronic School Book. Electronic School Book played a very important role, since this book serves as the supplement with economic value, beside the package book. Although the Electronic School Book is economical, the materials of the book is also complete. The students also could use the book anywhere using their personal laptop without printing it out. In the classroom, the teacher also often presented the book in the LCD projector to explain a certain concept. Moreover, the Electronic School Book was also used by the teacher to give exercises during the learning process. Therefore, the Electronic School Book was also maximally used to learn polyhedrons.

According to Hudoyo (2005), the way the students depended on their motivation and ability. Teachers should facilitate the emergence of their motivation, so that their ability may be optimal. One of the facilities provided by the teacher was various types of innovative learning media. It was also conducted by the teacher in MTs N Malang 1. The teacher tried to optimize his learning media and learning resources. He often updated and solved each hindrance in using the learning resources and media. For example, to solve a problem in presenting the material in the form of Power Point when the electricity was off, he tried to provide other learning resources and media that may be used without electricity, from the use of the package and Students' Worksheet and also other media in the classroom.

I Wayan Ponter (2009) stated that the form of geometrical illustrations are beneficial for the students to understand concepts and the application of concepts, therefore it may be used as media for developing, understanding, attracting the attention to and interest in problems, defining, guessing, forming preliminary understanding, looking at the relation and using visual facts as the basis for actual or intuitive understanding and reasoning. 
Therefore, it can be concluded that in learning polyhedrons which are also a subcategory of geometry, besides Power Point, other visual media should also be provided to anticipate if the electricity is off, so that in learning geometry, geometric illustrations may still be presented because using such illustrations the concepts of polyhedrons may be more meaningful.

\section{CONCLUSION:}

From the research conducted dealing with the learning of polyhedrons in Grade VIII-A MTs N Malang 1, it can be stated in the IT-based learning, various learning resources and media such as the mathematics teacher, the package books Grade VIII, other reference books such as Electronic School Books, Students' Worksheets, and other interactive learning media such as Power Point were made use of. In the IT-based learning dealing with polyhedrons, the students could learn actively in the classroom and still could make use of learning resources and media out of the classroom. However, there are some hindrances in the IT-based learning, namely internal and external hindrances. One of the internal hindrances is the teachers' less preparation in making the teaching materials, while the external hindrance is when the electricity is off, since the IT-based learning is dependent on electricity. To solve the problem, the teacher usually made use of other learning resources such as the package books and other media in the classroom such as wardrobes for cubes.

\section{REFERENCES}

AECT.(1996) Definisi Teknologi Pendidikan. Jakarta: CV. Rajawali

Aisah, Lusi Siti. 2012. Desain Didaktis Konsep Luas Permukaan dan Volume Prisma dalam Pembelajaran Matematika SMP.Jakarta: Universitas Pendidikan Indonesia

Angkowo. R, A.Kosasih. (2007). Optimalisasi Media Pembelajaran. Jakarta: PT. Grasindo

Burger, W. F., \& Culpepper, B. (1993) Restructuring Geometry. Chapter 8 in P. S. Wilson (Ed.), Research Ideas for the Classroom: High School Mathematics. New York: MacMillan.

Dewey, John (1916/1944). Democracy and Education. The Free Press. hlm. 1-4. ISBN 0684-83631-9

Anonymous. (2008). Evaluating, Selecting and Acquiring Learning Resources: A Guide. Canada: Society of Composers, Authors and Music Publishers of Canada

Hamalik, O. (1989). Media Pendidikan.Bandung :Penerbit Alumni.

Hudoyo, H. (2005). Pola Perilaku Pengajar dan Pelajar dalam Proses Belajar-Mengajar Matematika. Kapita Seleka Pembelajaran Matematika, Malang: UM Press

Pointer, I Wayan. (2009).Visualisasi Ungkapan Geometris Peserta didik SMP. Seminar Nasional Matematika 2009. ISBN : 979-8176-66-9

Sabri, Ahmad.2005. Strategi Belajar Mengajar dan Microteaching. Jakarta:Ciputat Press

Subandijah. 1983. Pengembangan dan Inovasi Kurikulum. Jakarta :Raja Grafindo Persada. UU No 20 Sisdiknas Tahun 2003 